\title{
Bioavailability of berberine: challenges and solutions
}

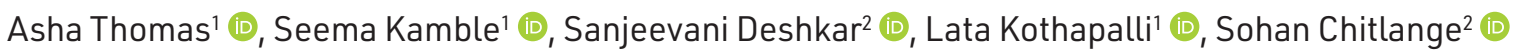 \\ 1Patil Institute of Pharmaceutical Sciences and Research, Department of Pharmaceutical Chemistry, Pimpri, Pune, MS, India \\ ${ }^{2}$ Patil Institute of Pharmaceutical Sciences and Research Department of Pharmaceutics, Pimpri, Pune, MS, India
}

ORCID IDs of the authors: A.T. 0000-0003-1058-8779; S.K. 0000-0003-0967-1225; S.D. 0000-0002-3393-717X;

L.K. 0000-0002-7412-5805; S.C. 0000-0002-9355-3303

Cite this article as: Thomas, A., Kamble, S., Deshkar, S., Kothapalli, L., \& Chitlange, S. (2021). Bioavailability of berberine: Challenges and solutions. Istanbul Journal of Pharmacy, 51(1), 141-153.

\begin{abstract}
Berberine is a quaternary benzylisoquinoline alkaloid with multiple pharmacological effects used for the treatment of hypertension, tumors, bacterial infections, inflammation, HIV, and cardiac diseases. In phase I clinical trials, berberine is safe at excessive doses but manifests poor bioavailability. Major challenges like poor absorption, rapid metabolism, and rapid systemic elimination are responsible for low plasma and tissue levels of berberine. Various strategies have been undertaken by several researchers to overcome this issue and enhance the bioavailability of berberine. This includes the design of new formulation strategies; novel drug delivery systems (NDDS) like liposomes, nanosized dosage forms, phospholipid complexes, mucoadhesive microparticles, and micoemulsions; the use of adjuvants; and the design of structural analogous of berberine. This review focuses on the occurrence of berberine in numerous plants and its pharmacological activities as evidenced through numerous preclinical and clinical studies. The later part of this review highlights the bioavailability issue of berberine which arises due to its poor absorption, elevated rate and extent of metabolism, and quick elimination and clearance from the body. A systematic effort has beenmade to analyze the various formulation strategies, including the design of newer berberine analogues and derivatives. These strategies can be further explored to increase the bioavailability, medicinal value, and application of this promising molecule.
\end{abstract}

Keywords: Berberine, bioavailability improvement, metabolism, pharmacokinetics

\section{INTRODUCTION}

Berberine (5,6-dihydro-9,10-dimethoxybenzo[g]-1,3-benzodioxolo[5,6-a]quinolizinium) (Figure 1) is an isoquinoline alkaloid with a molar mass of $336.3612 \mathrm{~g} / \mathrm{mol}$. It is present as a non-basic and quaternary protoberberine in several herbs, including European barberry, goldenseal, goldthread, Oregon grape, phellodendron, and tree turmeric (Neag et al., 2018). The reported uses of berberinecontaining species are summarized in Table 1. Berberine (BBR) is a yellowish crystalline powder with a faint characteristic odor and sour taste. It is moderately soluble in methanol, with marginally solubility in ethanol and water (Battu et al., 2010). Berberine is reactive to light and heat; when exposed to high temperature and light, it undergoes degradation and thus affects its stability (Neag et al., 2018). Several pharmacological effects of BBR are reported in literature, which includes anti-depressant (Sun et al., 2014), anti-atherosclerosis (Sarna, Wu, Hwang, Siow, \& O, 2010), anti-diarrheal (Zhang et al., 2012b), anti-osteoporosis (Lee et al., 2008), antihypercholesterolemia (Kong et al., 2008), and neuroprotective effects (Zhang et al., 2012a). Reports on the extraction of different BBR-employing techniques (classical and conventional methods) using different solvents like methanol, ethanol, and aqueous or acidified methanol/ethanol are available in literature. Conventional methods enhance the extraction efficiency andreduce extraction times and solvent volumes used in the extraction process when compared to the classical methods. BBR in plant extracts and in biological fluids have been quantified using analytical techniques like Ultra Violet spectroscopy (UV), High Performance Liquid Chromatography (HPLC), High Performance Thin Layer Chromatography (HPTLC), Thin Layer Chromatography (TLC), Capillary 


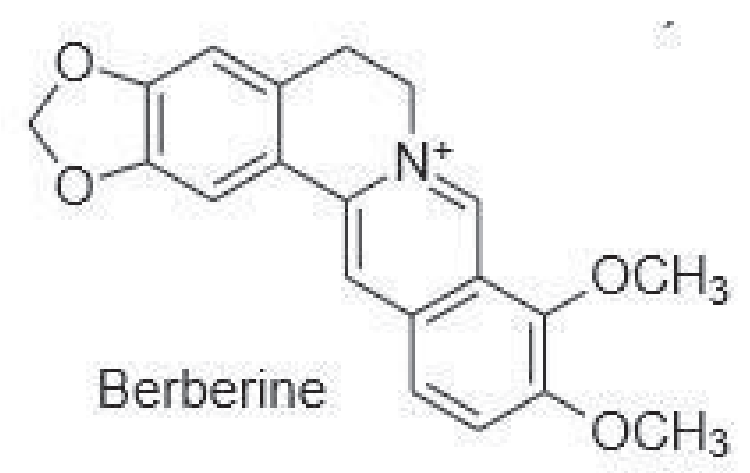

Figure 1. Structure of Berberine.

Electrophoresis (CE), and Liquid Chromatography coupled with Mass Spectrometry (LC-MS) (Neaget al., 2018).

BBR is present in several plants and is also reported to be responsible for numerous biological activities. Table 1 summarizes the plant species, content of berberine in plant parts, and their reported biological activities. BBR is also present in several marketed herbal preparations, either in pure chemical form as berberine or as plant extracts (ex. berberine in raw herb Daruharidra (Berberis aristata DC) (Neag et al., 2018). However the major drawback of BBR is its low bioavailability and poor pharmacokinetics, which is majorly responsible for its reduced efficacy. The foremost objective of this review is to discuss in detail the bioavailability, factors controlling bioavailability, and means to improve the bioavailability of BBR.

\section{Method of data collection}

A methodical collection of scientific literature, reports, experiments, case studies, and examination of work reported was performed with the help of data available from various sources, using several electronic literature databases such as Google Scholar, PubMed, Medline and Science direct databases. The information was searched up to April 2020. The search phrases used included: physicochemical, phytochemical and pharmacological properties, pharmacokinetics, metabolism, preclinical \& clinical studies, bioavailability, strategies reported for bioavailability enhancement of berberine, and preparations containing berberine.

\section{Selection criteria}

The data collected was further sorted on the basis of specific principles: articles based on the pharmacological screening of berberine for various activities; articles based on preclinical and clinical studies written with emphasis on the dose requirement of berberine and the bioavailability issues thereof; articles on problems of bioavailability of berberine; and papers on pharmacokinetics, tissue distribution, metabolism, and half-life were all included in the study. This review elaborates the varied strategies that were undertaken till date, with the objective to improve the bioavailability of berberine thereby enhancing its efficacy.

\section{Preclinical studies}

Preclinical case studies have reported that BBR is safe at higher doses but exhibits poor bioavailability. Deng et al., in their study, demonstrated that BBR was rapidly absorbed but eliminated very slowly in rat bodies after oral administration of combinations of Coptis (Coptidis rhizoma) and Evodia (Evodiae fructus) $(1.086 \mathrm{~g} / \mathrm{kg})$. The maximum plasma drug concentration achieved was $121.1 \pm 11.9 \mathrm{ng} / \mathrm{ml}$, appearing at $90 \mathrm{~min}$ of the study (Deng et al., 2008). In another study, BBR showed the maximum plasma concentration of $2.31 \mu \mathrm{g} / \mathrm{ml}$ at $0.5 \mathrm{~h}$ with slow elimination (5h) from rat bodies after administration of the Xiexin-Tang decoction at a dose of $20 \mathrm{ml} / \mathrm{kg}$ (Yi, Jian-Ping, $\mathrm{Xu}$, \& Lixin, 2006). The pharmacokinetics of BBR (200 mg/kg) and lysergol $(20 \mathrm{mg} / \mathrm{kg})$ in plasma after oral administration in rats was compared and reported by Patil et al. (2012). The findings of this study indicated that the pharmacokinetic profile of lysergol ( $\left.C_{\max }-316.54 \pm 26.83 \mathrm{ng} / \mathrm{ml}, T_{\max }-2.25 \mathrm{~h}, \mathrm{t}_{1 / 2}-21.3 \pm 1.75 \mathrm{~h}\right)$ was higher than BBR $\left(C_{\max }-112.30 \pm 12.07 \mathrm{ng} / \mathrm{ml}, T_{\max }-2.5 \mathrm{~h}, \mathrm{t}_{1 / 2^{-}}\right.$ $5.23 \pm 0.41 \mathrm{~h}$ ). However, the oral bioavailability of BBR was enhanced on concomitant administration with lysergol. Following oral administration of $90 \mathrm{mg} / \mathrm{kg} / \mathrm{d}$ of BBR to rats, improved lipid-lowering efficacy (46.2\%) was observed in comparison to BBRmonotherapy (26.8\%) (Kong et al., 2008).

A study provided the first preclinical evidence of effect of BBR loaded into chitosan nanoparticle (NP), and their surface modification induced neurodegenerative changes and hepatotoxicity in rats. BBR-NPs formulation (4 mg/kg, intraperitoneal, i.p.) was administered for 14 days, and on the $15^{\text {th }}$-day lipopolysaccharide (LPS), BBR-NPs showed significant implication on the neuroprotective and hepatoprotective effects (Soudi et al., 2019). Another study demonstrated the pharmacokinetic parameters of $\mathrm{BBR}$, following intragastric administration at a dose of $25 \mathrm{mg} / \mathrm{kg}$ in normal and diseased rats (post inflammatory irritable bowel syndrome). The findings showed that the $C_{\max }$ in the diseased animal group (18.53 $\pm 0.61 \mathrm{ng} / \mathrm{ml}$ at $15 \mathrm{~min})$, when compared to the normal control group $(16.74 \pm 4.47 \mathrm{ng} / \mathrm{ml}$ at $15 \mathrm{~min}$ ) was increased significantly while CL/F was decreased (Gong et al., 2014a).

The mean plasma concentration vs. time profile after intragastric (i.g.) administration of Rhizoma coptidis extract ( $96 \mathrm{mg} / \mathrm{kg}$ ) containing $22 \mathrm{mg} / \mathrm{kg}$ berberine was also studied. It was observed that BBR was absorbed quickly in the body within 15 min of the study in both the normal control and the diseased groups (post inflammatory irritable bowel syndrome). It was noteworthy that the plasma drug concentration of BBR remarkably increased in diseased model group $(39.2 \pm 7.9 \mathrm{ng} / \mathrm{ml}$ at $15 \mathrm{~min})$ compared to the normal control group (20.0 \pm 12.1 $\mathrm{ng} / \mathrm{ml}$ at $15 \mathrm{~min})$. However, compared to the normal control group $(198.6 \pm 75.4 \mathrm{~L} / \mathrm{h} / \mathrm{kg})$, the diseased model group $(124.3 \pm 27.4 \mathrm{~L} / \mathrm{h} / \mathrm{kg})$ demonstrated slower elimination of BBR (Gong et al., 2014a). The pharmacokinetics of BBR following oral administration $(20 \mathrm{mg} / \mathrm{kg}$ ) to normal and Type-2 diabetes mellitus (T2DM)-induced rats (model group) exhibited increase in $C_{\max }$ and $T_{\max }$ in T2DM group $(34.41 \pm 4.25 \mu \mathrm{g} / \mathrm{ml}$ at $2.24 \mathrm{~h})$ when compared to the normal group $(17.35 \pm 3.24 \mu \mathrm{g} /$ $\mathrm{ml}$ at 2.04h) (Jia, Xu and Xu, 2017).

\section{Clinical studies}

A clinical study, carried out in 50 patients with hypercholesterolemia on short-term administration of oral nutraceutical combination (NC) consisting of $500 \mathrm{mg}$ BBR, $200 \mathrm{mg}$ red yeast rice, and $10 \mathrm{mg}$ policosanols daily for 6 weeks, decreased 
Table 1. Uses of Berberine containing species.

\begin{tabular}{|c|c|c|c|}
\hline Biological name & Berberine content (\%) & Activity & Reference \\
\hline Berberis aristata & Root $-4 \%$ & $\begin{array}{l}\text { Antimicrobial activity } \\
\text { Anti-osteoporotic activity } \\
\text { Antidiarrheal activity } \\
\text { Antihyperglycemic activity } \\
\text { Cytotoxic activity }\end{array}$ & $\begin{array}{l}\text { Singh, Srivastava and Rawat, } \\
\text { 2007; } \\
\text { Yogesh et al., 2011; Joshi, } \\
\text { Shirkhedkar,Prakash, \& Mahesh- } \\
\text { wari, 2011; Semwal, Gupta,Singh, } \\
\text { Kumar, \& Giri, 2009; Das, Das, } \\
\text { Mazumder, Dasand Basu, } 2009\end{array}$ \\
\hline Berberis asiatica & $\begin{array}{l}\text { Root }-2.09 \% \\
\text { Steam- } 1.29 \%\end{array}$ & $\begin{array}{l}\text { Antimicrobial activity } \\
\text { Antibacterial activity } \\
\text { Anti-diabetic activity } \\
\text { Anticancer activity }\end{array}$ & $\begin{array}{c}\text { Bhandari, Nath, Ray, \& Tewari, } \\
\text { 2000; } \\
\text { Singh, Vishnoi, Dhingra, \& Kishor, } \\
\text { 2012; } \\
\text { Singh, \& Jain,2010 }\end{array}$ \\
\hline $\begin{array}{l}\text { B. chitria Buch-Ham. } \\
\text { ex. Lindl }\end{array}$ & $5.0-4.2 \%$ & $\begin{array}{l}\text { Antimicrobial activity } \\
\text { Wound healing activity }\end{array}$ & $\begin{array}{l}\text { Eto, Inoue, \& Kadowaki, 2012; } \\
\text { Biswas \& Mukherjee, } 2003\end{array}$ \\
\hline B. lycium Royle & $2.3 \%$ & $\begin{array}{l}\text { Antimicrobial activity } \\
\text { Antihyperglycemic activity } \\
\text { Anti-diabetic activity } \\
\text { Wound healing activity }\end{array}$ & $\begin{array}{l}\text { Hussain, Khan, Habib, \& Hussain, } \\
\text { 2011; } \\
\text { Jigneshkumar, 2011; } \\
\text { Gulfraz, 2008; Pirbalouti, Azizi, } \\
\text { Koohpayeh, \& Hamedi, } 2010\end{array}$ \\
\hline B.vulgaris L. & $5 \%$ & $\begin{array}{l}\text { Antibacterial activity } \\
\text { Antioxidant activity } \\
\text { Hepatoprotective activity } \\
\text { Antimicrobial activity }\end{array}$ & $\begin{array}{c}\text { Villinski et al.,2003; } \\
\text { Tomosaka et al., 2008; } \\
\text { Agarwal,Srivastava, Saxena, } \\
\text { \& Kumar, 2006; Owokotomo \& } \\
\text { Owoeye, } 2011\end{array}$ \\
\hline $\begin{array}{l}\text { Coscinium fenestra- } \\
\text { tum (Goetgh.) Colebr. }\end{array}$ & Stem $3.5 \%$ & $\begin{array}{c}\text { Antidiabetic activity } \\
\text { Antibacterial effect } \\
\text { Antihyperglycemic activity }\end{array}$ & $\begin{array}{l}\text { Shirwaikar, Rajendran and I. S.R. } \\
\text { Punitha, 2005a; } \\
\text { Nair, Narasimhan, Shiburaj, \& } \\
\text { Abraham, 2005; } \\
\text { Shirwaikar, Rajendran and I. S.R. } \\
\text { Punitha, 2005b. }\end{array}$ \\
\hline $\begin{array}{l}\text { Mahonia napaulensis } \\
\text { DC. }\end{array}$ & Root $0.5 \%$ & $\begin{array}{c}\text { Antifungal activity } \\
\text { Anti-inflammatory activity }\end{array}$ & $\begin{array}{c}\text { Bajpai and Vankar, 2007; Andrei- } \\
\text { cut et al., } 2018\end{array}$ \\
\hline $\begin{array}{l}\text { Thalictrum foliolosum } \\
\text { DC. }\end{array}$ & Rhizome $0.35 \%$ & $\begin{array}{l}\text { Anti-gastric ulcer activity } \\
\text { Antiplasmodial activity }\end{array}$ & $\begin{array}{c}\text { Malairajan, Gopalakrishnan, Nara- } \\
\text { simhan, \& Veni, 2008; } \\
\text { Das, Rabha, Talukdar, Goswami, } \\
\text { \& Dhiman, 2016; }\end{array}$ \\
\hline Berberis aquifolium & Rhizome 8-9\% & $\begin{array}{l}\text { Antimicrobial activity } \\
\text { Antiradical and antioxidant }\end{array}$ & $\begin{array}{l}\text { Cernakovaand Koštálová, 2002; } \\
\text { Rackova, Majekova, Kost, \& Ste- } \\
\text { fek, } 2004\end{array}$ \\
\hline Berberis thunbergii & Rhizome 8-9\% & $\begin{array}{c}\text { Antioxidant and } \\
\text { Anti-Inflamantory activity }\end{array}$ & Zhang, Schutzki and Nair, 2013 \\
\hline Coptis teeta & Rhizome 8-9\% & $\begin{array}{l}\text { Antibacterial activity } \\
\text { Inhibitors of topoisomerase }\end{array}$ & $\begin{array}{c}\text { Kong et al., 2009; Kobayashi et } \\
\text { al., } 1995\end{array}$ \\
\hline B.lyceum & Steam $-4 \%$ & Antimicrobial activity & Ali, Uddin and Jalal, 2015 \\
\hline Palmatine & $0.30 \%$ & $\begin{array}{c}\text { Antifungal activity } \\
\text { Inhibition of tyrosine hydroxylase }\end{array}$ & $\begin{array}{l}\text { Li et al., 2015; Lee, Zhang and } \\
\text { Kim, } 1996\end{array}$ \\
\hline Goldenseal & $0.5-6 \%$ & $\begin{array}{c}\text { Antibacterial activity } \\
\text { Inhibits human CYP3A activity } \\
\text { Human cytochrome p450 inhibi- } \\
\text { tion }\end{array}$ & $\begin{array}{l}\text { Ettefagh, Burns, Junio, Kaatz, \& } \\
\text { Cech, 2011; Gurley et al., 2008; } \\
\text { Chatterjee and Franklin, 2003, }\end{array}$ \\
\hline Goldthread & $8-12 \%$ & $\begin{array}{l}\text { Hair growth-promoting activity } \\
\text { Inhibit prostate cancer cell prolif- } \\
\text { eration and NF-Kbsignaling }\end{array}$ & $\begin{array}{l}\text { Zhao, Collier, Huang, \& Whelan, } \\
2014\end{array}$ \\
\hline
\end{tabular}


the atherogenic profile and lipid levels in the hypercholesterolemic patients (Affuso, Ruvolo, Micillo, Saccà, \& Fazio, 2010). Another study showed that 40 hyperlipidemic patients on administration of BBR alone (500 mg/day) against BBR (500mg/ day) combined with $10 \mathrm{mg}$ policosanol and $3 \mathrm{mg} /$ day red yeast extract for 4 weeks exhibited decreased TG (triglyceride) and LDL-C (low density lipoprotein cholesterol) in the combination group by $26 \%$ and $25 \%$ respectively when compared to BBR alone (22\% and 20\% respectively) (Cicero, Rovati and Setnikar, 2007). Another clinical study in 97 T2DM patients (type-2 diabetes mellitus) suggested the insulin receptor (InsR)-upregulating and glucose-lowering activities of BBR $(1 \mathrm{~g} / \mathrm{d}$ for 2 months). In these patients, the FBG (fasting blood glucose), HbA1c (Hemoglobin A1c), and TG (triglyceride) levels were significantly reduced by $25.9 \%, 18.1 \%$, and $17.6 \%$, respectively, as compared to their levels prior to the treatment. In patients affected with chronic hepatitis B and C, the FBG and TG levels were significantly lowered after treatment with berberine (Zhang et al., 2010). In another study, which observed the effect of either placebo or a proprietary nutraceutical combination consisting of BBR, policosanol, and red yeast rice in 64 patients with metabolic syndrome after 18 weeks of treatment, a significant reduction in the homeostasis model assessment of insulin resistance (HOMA-IR) index and low density lipoprotein-cholesterol (LDL-C) in the nutraceutical combination group compared with placebo was observed (HOMA: $-0.6 \pm 1.2 v s$ 0.4 $\pm 1.9 ; p<0.05$ and LDL-C: $-0.82 \pm 0.68 v s-0.13 \pm 0.55$ $\mathrm{mmol} / \mathrm{L} ; \mathrm{p}<0.0001)$. In addition, significant reduction in blood glucose and insulin levels and increase in endothelial- dependent FMD (flow mediated vasodilation) (1.9 $\pm 4.2 ; p<0.05)$ were also observed (Affuso et al., 2012). A trial carried out on women affected by polycystic ovary syndrome showed that, in the treatment with BBR when compared to metformin treatment, similar decrease in waist circumference and waist-to-hip ratio $(p<0.01), F P G$ (fasting plasma glucose) and FPI (fasting plasma insulin), insulin area under the curve, and HOMA-IR $(p<0.05)$ were recorded (Wei et al., 2012). Table 2 shows the comparative plasma and tissue levels of berberine in animals and humans through different routes of administration.

\section{Challenges in the bioavailability of berberine}

The bioavailability of any agent within the body is foreshortened owing to its short inherent activity, poor absorption, elevated rate of metabolism, the formation of metabolic products, and/ or the quick elimination and clearance from the body. Studies to date have suggested the utility of BBR as a therapeutic agent for the treatment of various ailments. However, several previous studies related to the absorption, distribution, metabolism, and excretion of BBR indicate poor absorption with rapid metabolism of BBR that significantly affects its bioavailability. Studies of BBR in rats have reported low oral bioavailability of $<1 \%(0.68 \%$ and 0.36\%) (Chen et al., 2011; Liu et al., 2010) due to extensive intestinal first-pass elimination, interaction with P-glycoprotein (Pg-P) efflux pumps, and the high distribution in the liver. In this section, problems of BBR bioavailability such as low plasma levels, limited tissue distribution, apparent rapid metabolism, and short half-life are described in detail.

Table 2. Plasma and Tissue levels of berberine in animals and human through different routes of administration.

\begin{tabular}{|c|c|c|c|c|c|c|}
\hline Species & Route & Dose & Plasma/Tissue & Time & Conc. level & Ref. \\
\hline Rat & Intragastric & $96 \mathrm{mg} / \mathrm{kg}$ & Plasma & $15 \mathrm{~min}$ & $20.04 \pm 12.14 \mathrm{ng} / \mathrm{mL}$ & Gong et al., 2014b \\
\hline Rat & Intravenous & $3 \mathrm{mg} / \mathrm{kg}$ & Hippocampus & $3.6 \mathrm{~h}$ & $272 \pm 12 \mathrm{ng} / \mathrm{g}$ & Wang et al., 2005b \\
\hline \multirow[t]{9}{*}{ Rat } & Oral & 200 mg/kg & Tissue & $1.33 \mathrm{~h}$ & $25.85 \pm 7.34 \mu \mathrm{g} / \mathrm{mL}$ & Tan et al., 2013 \\
\hline & & & Liver & $8 \mathrm{~h}$ & $68.19 \mathrm{ng} / \mathrm{g}$ & \\
\hline & & & Kidney & $12 \mathrm{~h}$ & $13.92 \mathrm{ng} / \mathrm{g}$ & \\
\hline & & & Lung & $4 \mathrm{~h}$ & $11 \mathrm{ng} / \mathrm{g}$ & \\
\hline & & & Muscle & $12 \mathrm{~h}$ & $5 \mathrm{ng} / \mathrm{g}$ & \\
\hline & & & Brain & $12 \mathrm{~h}$ & $8 \mathrm{ng} / \mathrm{g}$ & \\
\hline & & & Heart & $24 \mathrm{~h}$ & $9.5 \mathrm{ng} / \mathrm{g}$ & \\
\hline & & & Pancreas & $2 \mathrm{~h}$ & $9.8 \mathrm{ng} / \mathrm{g}$ & \\
\hline & & & Fat & $2 \mathrm{~h}$ & $10 \mathrm{ng} / \mathrm{g}$ & \\
\hline Rat & Oral & $4 \mathrm{mg} / \mathrm{kg}$ & Plasma & $0.083 \mathrm{~h}$ & $1205.3 \pm 270.9 \mathrm{ng} / \mathrm{mL}$ & $\begin{array}{l}\text { Liu, et al., Hao, Xie, Lv, } \\
\text { Liu, \& Wang, } 2009\end{array}$ \\
\hline Rat & Oral & 200 mg/kg & Plasma & $2.5 \mathrm{~h}$ & $112.30 \pm 12.07 \mathrm{ng} / \mathrm{mL}$ & Wang et al., 2005a \\
\hline Human & Oral & $400 \mathrm{mg}$ & Plasma & $9.8 \pm 6.6 \mathrm{~h}$ & $0.4356 \pm 0.2792 \mathrm{ng} / \mathrm{mL}$ & $\begin{array}{c}\text { Inbaraj, kukielczak, } \\
\text { Bilski, Sandvik, \& } \\
\text { Chignell, } 2001\end{array}$ \\
\hline Mice & Intravenous & $2.5 \mathrm{mg}$ & Plasma & $0.083 \mathrm{~h}$ & $0.712 \mu \mathrm{g} / \mathrm{mL}$ & Wang et al., 2011 \\
\hline Rabbits & Intragastric & $50 \mathrm{mg} / \mathrm{kg}$ & Plasma & $1.09 \pm 0.37 \mathrm{~h}$ & $129.49 \pm 24.54 \mathrm{ng} / \mathrm{mL}$ & Hu et al., 2013 \\
\hline Rat & Intragastric & $25 \mathrm{mg} / \mathrm{kg}$ & Plasma & $15.0 \mathrm{~min}$ & $18.53 \pm 0.61 \mathrm{ng} / \mathrm{mL}$ & Yu et al., 2017 \\
\hline
\end{tabular}




\section{Plasma concentration}

One of the major problems associated with BBR is its extremely low plasma levels. The low plasma concentration of BBR is mainly related to the following pharmacokinetic causes: 1. extensive metabolism in the gut and/or liver, 2. marked excretion to intestinal lumen, bile, and urine, as well as enterohepatic circulation, 3. poor absorption, 4. predominant tissue distribution.

When BBR was given orally at a dose of $20 \mathrm{~mL} / \mathrm{kg}$ to rats, a maximum plasma concentration of $2.31 \mu \mathrm{g} / \mathrm{mL}$ was observed at $0.5 \mathrm{~h}$ of the study and high concentration until $5 \mathrm{~h}$; BBR was slowly eliminated from the rat bodies. Following intravenous administration of $3 \mathrm{mg} / \mathrm{kg}$ of BBR to rats, the concentration of BBR in plasma and hippocampus was found to be $38.5 \mathrm{ng} / \mathrm{mL}$ at $4 \mathrm{~h}$ and $30.7 \mathrm{ng} / \mathrm{mL}$ at $48 \mathrm{~h}$, respectively, with fast elimination (1.13 h) from the body (Wang et al., 2005). The elimination phase of BBR in the liver was significantly slower than that in blood. When BBR at a dose of $20 \mathrm{mg} / \mathrm{kg}$ was administered via femoral vein by i.v. bolus injection, it was detected in the liver up to 80 min post administration. BBR in bile was detected for up to $6 \mathrm{~h}$; the disposition of BBR in bile is higher as compared to that of the liver and blood (Tsai \& Tsai, 2004).

\section{Tissue distribution}

Uptake and distribution of BBR in body tissues is very important for its biological activity, yet only a limited number of studies have been addressed this issue. Although BBR is present at a very low level in blood and its bioavailability was reported to be less than $1 \%$, the pharmacological effect of BBR can be correlated with its high tissue distribution. BBR at a dose of $200 \mathrm{mg} / \mathrm{kg}$ via oral route showed a maximum amount in the liver $(68.19 \mathrm{ng} / \mathrm{g})$ 8 h after dosing. A maximum concentration of BBR was observed at $24 \mathrm{~h}$ in the heart; $12 \mathrm{~h}$ in the kidneys, muscles, and brain; $4 \mathrm{~h}$ in the lungs; and $2 \mathrm{~h}$ in the pancreas (Tan et al., 2013). BBR can easily penetrate the blood-brain barrier, with rapid accumulation in the hippocampus region after intravenous administration, followed by slow elimination (Tsai \& Tsai, 2004). Tissue distribution of BBR in rats after oral administration of $6 \mathrm{~g} / \mathrm{kg}$ for 1 week was determined by a HPLC method. Repeated administration of BBR dose increased its concentration in the heart, liver, and kidneys, with lower concentration in the spleen and lungs (Xiao et al., 2018). When BBR and 8-cetylberberine (8-BBR-C16) was given orally at a dose of $80 \mathrm{mg} / \mathrm{kg}$ to rats, the plasma concentration increased 2.8 times. Tissue distribution was determined by RPHPLC; a maximum concentration (3731.82 ng/g)was found in the lungs (Hu, Chen, Zou, Li, \& Ye, 2014).

\section{Metabolites}

Numerous studies have assessed the metabolism of berberine in rats and in humans. Once absorbed, BBR is subjected to conjugations like sulfation and glucuronidation at various tissue sites. BBR was reported to undergo extensive metabolism when administered orally to rats. The liver was indicated as the major organ responsible for the metabolism of BBR. Following oral administration of BBR to rats $(100 \mathrm{mg} / \mathrm{kg}$ ) and humans $(300 \mathrm{mg} /$ $\mathrm{kg}$ ), the urinary metabolites analyzed indicated that BBR undergoes similar bio-transformations in both rats and humans. Nine metabolites were isolated, demethyleneberberine-2-sulfate (HM1 and HM3), jatrorrhizine-3-O-sulfate (HM5), thalifendine
(RM5), jatrorrhizine-3-O- $\beta-\mathrm{D}-\mathrm{glucuronide}(\mathrm{HM} 2)$, thalifendine10-O- $\beta$-D- glucuronide (HM3), berberrubine-9-O- $\beta$-D- glucuronide (HM4 and HM2), 3,10-demethylpalmatine-10-O-sulfate HM6 and RM4), columbamin-2-O- $\beta$-D-glucuronide (HM7),

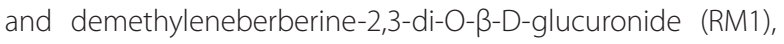
by HPLC (Qiu et al., 2008). After the oral administration of BBR (40 mg/kg), the rat liver tissues and bile samples collected and evaluated showed the presence of four main metabolites (berberrubine, thalifendine, demethyleneberberine, and jatrorrhizine), detected in liver after $0.5 \mathrm{~h}$ and in bile $1 \mathrm{~h}$ after the study (Wang, Feng, Chai, Cao, \& Qiu, 2017). Liquid chromatography coupled to ion trap time-of-flight mass spectrometry (LC/MSIT-TOF) was used for the identification of major metabolites of $B B R$, thalifendine (M1), berberrrubine (M2), and jatrorrhizine (M4), in the liver and kidney, respectively. The level of AUC (area under the concentration-time curve) for metabolites of BBR in the liver was 40 times higher and in kidney seven times higher than that in plasma (Tan et al., 2013). The LC/MS analysis of the plasma samples of BBR identified berberrubine, demethyleneberberine, and their glucuronide analogous as the important metabolites seen after oral administration ( $4 \mathrm{mg} / \mathrm{kg}$, berberine) to rats (Liu et al., 2009). After oral administration of BBR (200 mg/ $\mathrm{kg}$ ) to rats, a total of 16 berberine related metabolites including 10 phase-I metabolites and six phase-II metabolites were identified and clarified by LC-IT-TOF/MS system (Ma et al., 2013). Figure 2 represents the in vivo phase I metabolites of berberine.

\section{Half-life}

The systemic elimination or clearance of BBR from the body is also an important factor which determines its relative biological activity. With the lower dose of BBR (3 mg/kg) administered intravenously to rats, the elimination half-life in thalamus was found to be $14.6 \mathrm{~h}$, which indicates that BBR quickly distributes itself in the thalamus and can pass through the blood-brain barrier (Wang et al., 2005). The kinetic characteristics of BBR are different in the hippocampus and plasma. In the in vivo study, after $3 \mathrm{mg} / \mathrm{kg}$ i.v. doses were given to rats, BBR was eliminated from plasma in $1.13 \mathrm{~h}$ and from the hippocampus in $12 \mathrm{~h}$ (Wang et al., 2005). Another study reported that, with the higher dose of BBR (150 mg/kg) by oral gavage in groups i.e. G1 (untreated), G2 (Biofield treated berberine), and G3 (Biofieldtreated animals who received biofielduntreated berberine) groups, plasma clearance of BBR decreased to 81\% (G2) and 50\% (G3) as compared to the control group (Inbaraj, Kukielczak, Bilski, Sandvik, \& Chignell, 2001). After oral administration of BBR at a dose of $200 \mathrm{mg} / \mathrm{kg}$ in rats, $83 \%$ of BBR was excreted mainly as thalifendine from bile ( $24 \mathrm{~h}$ ) and as thalifendine and berberrubine (78\%) on urinary excretion (48 h) (Ma et al., 2013).

\section{Solutions to improve the bioavailability of berberine}

The low oral bioavailability of berberine is one of the prime hurdles for market approval of BBR. The absorption, biodistribution, metabolism, and elimination studies of BBR have unfortunately shown poor absorption, rapid metabolism, and elimination of BBR as major reasons for its poor bioavailability. One of the approaches to overcome the low gastrointestinal absorption due to extensive intestinal first-pass effect resulting in low plasma levels of BBR involves effective modulation of the P-gp mediated efflux of BBR. Studies have focused on 


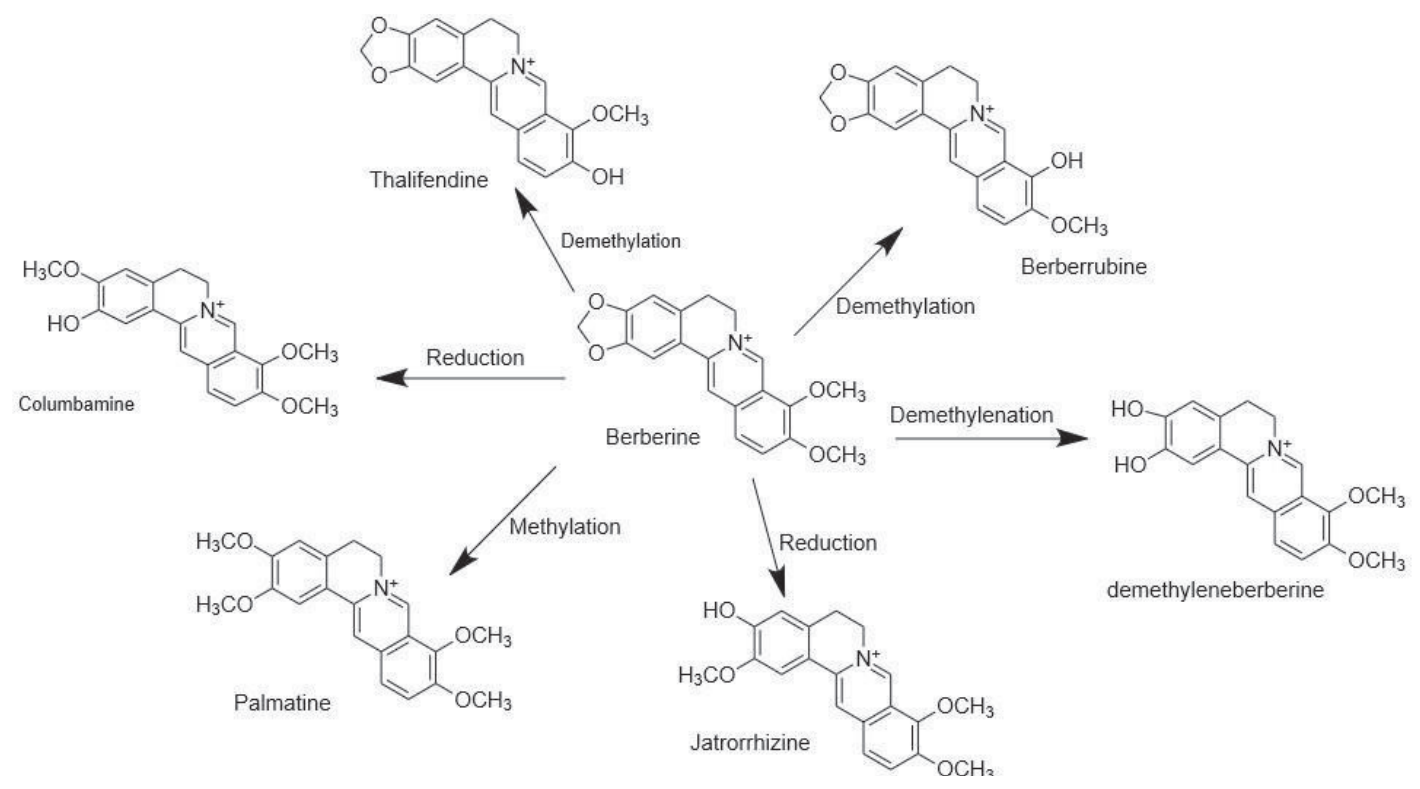

Figure 2. Phase -1 metabolites of berberine in vivo.

the effective utilization of pharmaceutical excipients that have P-gp inhibitory effects. Several novel dosage forms like nanosized dosage forms, liposomes, micelles, and phospholipid complexes are optimistic formulations which overcome the problems of BBR by imparting longer circulation, better permeability, and resistance to metabolic processes (Chen et al., 2011). The strategies to improve the bioavailability of BBR are summarized in Table 3.

\section{Nano-sized dosage forms}

Presently, nano-sized technology is an important solution for bioavailability enhancement of therapeutic agents. BBR has been incorporated in nanoparticle-based delivery systems to circumvent the pitfalls of its poor bioavailability. The synthesis, physicochemical characterization, and antimicrobial activity of nanoparticles of BBR with sizes less than $110 \mathrm{~nm}$ has been reported. Antimicrobial activity of berberine nanoparticles prepared by evaporative precipitation of nanosuspension (EPN) and anti-solvent precipitation with a syringe pump (APSP) method have shown two-to-four-fold increase in activity against gram-negative bacteria (Sahibzada et al., 2018). Berberine-loaded solid lipid nanoparticles (BBR-SLNs) for topical application were developed and characterized as having a $76.8 \mathrm{~nm}$ particle size. Single doses of BBR-SLNs ( $50 \mathrm{mg} / \mathrm{kg}$ ) compared to BBR alone showed substantial enhancement in the peak plasma concentration, area under the curve, and mean residence time after oral administration to rats. BBR-SLNs at a high dose $(100 \mathrm{mg} / \mathrm{kg})$ showed more significant effect when compared to an equivalent dose of BBR (Xue et al., 2013). Polymer-lipid hybrid nanoparticles (PEG-lipid-PLGA NPS) loaded with BBR phospholipid complex and BBR-soybean phosphatidylcholine complex (BBR-SPC) enhanced the oral BBR efficiency and can be used to enhance the liposolubility of BBR and improve the affinity with the biodegradable polymer in order to increase the drug-loading capacity and controlled/sustained release. The PEG-lipid-PLGA NPS/BBR-SPC enhanced the oral relative bioavailability (approximately 343\%) when compared with the free BBR suspension group after administration at a dose of $50 \mathrm{mg} /$ $\mathrm{kg}$ via intragastric gavage in rats (Yu et al., 2017). The seleniumcoated nanostructured lipid carriers (SeNLCs), $160 \mathrm{~nm}$ in particle size, were formulated, which enhanced the oral bioavailability with an entrapment efficacy (EE) of $90 \%$ of BBR. An in vivo study in rats (50 mg/kg, BB-SeNLCs) by oral route demonstrated enhanced oral bioavailability (approximately 6.63 times) when compared to a BBR solution. The plasma concentration of BBR was quantified by ultra-performance liquid chromatographyquadrupole time-of-flight mass spectrometry (UPLC-QTOF/ MS) (Yin, Hou, Yin, \& Song, 2017). Development of novel nanosystems shelled with heparin for BBR delivery increased the suppressive effect of BBR on $H$. pylori growth while efficiently reducing the cytotoxic effects in $\mathrm{H}$. pylori-infected cells. In this research, the nanosystem was prepared by the simple ionic gelation method (Chang et al., 2011).

\section{Nanocrystals dosage form}

Nanocrystals are a major alternative for enhancing the poor oral bioavailability of water-soluble drugs as compared to other nanocarrier drug delivery systems. Formation of nanocrystals enhances the solubility and dissolution rate of poorly soluble drugs (Liu, Tu, Cheng,Feng, \& Jin, 2020). Semi-crystalline nanoparticles (NPs) prepared by evaporative precipitation of nanosuspension (EPN) and anti-solvent precipitation with a syringe pump (APSP) were prepared to overcome the poor solubility of BBR and improve the dissolution rate and bioavailability of BBR. NPs prepared by the EPN method showed better results than those prepared by the APSP method in terms of solubility and dissolution rate (Sahibzada et al.,2018). Another study showed improved oral bioavailability using Brij-S20 (BS20)-modified nanocrystal formulation (BBR-BS20-NCs). A significant improvement in the maximum concentration $\left(C_{\max }\right)$ and area under the curve $\left(A \cup C_{0-t}\right)$ in the pharmacokinetic studies were observed (Xiong et al., 2018).

\section{Liposomes, micelles, and phospholipid complexes}

Liposome is an excellent drug delivery system as it can be used to incorporate both hydrophilic and hydrophobic mol- 
Table 3. Formulation development strategies for bioavailability enhancement of berberine.

\begin{tabular}{|c|c|c|c|}
\hline Type of dosage form & Methodology used & $\begin{array}{l}\text { Improved PK/Bioavailability } \\
\text { parameters }\end{array}$ & Reference \\
\hline \multirow[t]{3}{*}{$\begin{array}{l}\text { Nano sized dosage } \\
\text { form }\end{array}$} & $\begin{array}{l}\text { Berberine loaded solid lipid nanopar- } \\
\text { ticles (BBR-SLNs) }\end{array}$ & $\begin{array}{l}\text { Substantial enhancement in } \\
\text { the peak plasma concentra- } \\
\text { tion, area under the curve, and } \\
\text { mean residence time. }\end{array}$ & Xue et al., 2013 \\
\hline & $\begin{array}{l}\text { Polymer-lipid hybrid nanoparticles } \\
\text { loaded with BBR phospholipid complex } \\
\text { (PEG-lipid-PLGA NPs/BBR-SPC) }\end{array}$ & $\begin{array}{l}\text { Enhanced the oral relative } \\
\text { bioavailability }\end{array}$ & Yu et al.,2017 \\
\hline & $\begin{array}{l}\text { Selenium-coated nanostructured lipid } \\
\text { carriers (SeNLCs) }\end{array}$ & $\begin{array}{l}\text { Enhanced the oral bioavail- } \\
\text { ability with an entrapment } \\
\text { efficacy (EE) of } 90 \% \text {. }\end{array}$ & $\begin{array}{l}\text { Yin, Hou, Yin, \& } \\
\text { Song, } 2017\end{array}$ \\
\hline $\begin{array}{l}\text { Nanocrystals dosage } \\
\text { form }\end{array}$ & $\begin{array}{l}\text { Berberine -Brij-S20 - modified nanocrys- } \\
\text { tal formulation (BBR-BS20-NCs) }\end{array}$ & $\begin{array}{l}\text { Significant improvement in } \\
\text { the maximum concentration } \\
\left(C_{\text {max }}\right) \text { and area under the } \\
\text { curve }\left(A \cup C_{0-t}\right)\end{array}$ & Xiong et al., 2018 \\
\hline \multirow[t]{2}{*}{ Liposomes } & Berberine-loaded solid proliposomes & $\begin{array}{l}\text { Higher blood plasma concen- } \\
\text { tration }(227.08 \mu \mathrm{g} / \mathrm{ml}) \text {. In vitro } \\
\text { drug release study indicated } \\
\text { sustained release of berber- } \\
\text { ine-proliposomes. }\end{array}$ & Jia et al., 2019 \\
\hline & Chitosan-coated nano-liposome & $\begin{array}{l}\text { In vitro study showed im- } \\
\text { proved stability and delayed } \\
\text { BH release in the simulated } \\
\text { gastrointestinal (GI) environ- } \\
\text { ment }\end{array}$ & Nguyen et al., 2014 \\
\hline \multirow[t]{2}{*}{ Micelles } & $\begin{array}{l}\text { Berberine loaded anhydrous reverse } \\
\text { micelle (ARMs) formulation }\end{array}$ & $\begin{array}{l}\text { Significantly increased plasma } \\
\text { level of active BBR in rats }\end{array}$ & Wang et al., 2011 \\
\hline & $\begin{array}{l}\text { Berberine-mixed1,2-distearoyl-sn- } \\
\text { glycero-3-phosphoethanolamine-N- } \\
\text { [methoxy (polyethyleneglycol)- 2000] } \\
\text { (PEG-PE) and d- } \alpha \text {-tocopheryl polyethyl- } \\
\text { ene glycol } 1000 \text { succinate (TPGS) micelle } \\
\text { system (mMic) }\end{array}$ & $\begin{array}{l}\text { Intestinal absorption en- } \\
\text { hancement effect of approxi- } \\
\text { mately } 3-5 \text { fold (maximum } \\
\text { plasma concentration of } 1.22 \\
\mathrm{mg} / \mathrm{kg} \text { ) }\end{array}$ & $\begin{array}{l}\text { Shen, Kim, Yao, \&El- } \\
\text { bayoumi, } 2016\end{array}$ \\
\hline \multirow[t]{5}{*}{ Microemulsion } & $\begin{array}{l}\text { Berberine-loaded microemulsion formu- } \\
\text { lation }\end{array}$ & $\begin{array}{l}\text { Improved the bioavailability } \\
6.47 \text { times greater than that of } \\
\text { the berberine tablet }\end{array}$ & Gui et al., 2008 \\
\hline & $\begin{array}{l}\text { Berberine hydrochloric nanometer mi- } \\
\text { croemulsion }\end{array}$ & $\begin{array}{l}\text { Improved the efficiency of } \\
\text { antibacterial activity }\end{array}$ & $\begin{array}{l}\text { Wu, Zhu, \& Zhu, } \\
2009\end{array}$ \\
\hline & $\begin{array}{l}\text { Self-microemulsifying drug delivery } \\
\text { system (SMEDDS) }\end{array}$ & $\begin{array}{l}\text { In vitro study showed that the } \\
\text { release of BBR from SMEDDS } \\
\text { was faster ( } 5 \mathrm{~h} \text { ) than the com- } \\
\text { mercial tablet. In the in vivo } \\
\text { study plasma concentration } \\
\text { was } 163.4 \% \text { higher than the } \\
\text { commercial tablet. }\end{array}$ & Zhu et al., 2013 \\
\hline & $\begin{array}{l}\text { Cremophore- integrated chylomicron } \\
\text { "cremochylomicrons" loaded with ber- } \\
\text { berine }\end{array}$ & $\begin{array}{l}\text { Inhibited the BBR absorp- } \\
\text { tion }(43 \%) \text { and confirmed the } \\
\text { lymphatic targeting ability of } \\
\text { cremochylomicrons. }\end{array}$ & $\begin{array}{l}\text { Elsheikh, Elnaggar, } \\
\text { Hamdy, \& Abdallah, } \\
2018\end{array}$ \\
\hline & Berberine-loaded chylomicron & $\begin{array}{l}10.5 \text {-fold enhancement in } \\
\text { intestinal permeability over } \\
\text { free berberine }\end{array}$ & $\begin{array}{l}\text { Godugu, Patel, Dod- } \\
\text { dapaneni, Somago- } \\
\text { ni, \& Singh, } 2014\end{array}$ \\
\hline
\end{tabular}


Table 3. Continue.

\begin{tabular}{|c|c|c|c|}
\hline Type of dosage form & Methodology used & $\begin{array}{l}\text { Improved PK/Bioavailability } \\
\text { parameters }\end{array}$ & Reference \\
\hline \multirow[t]{2}{*}{$\begin{array}{l}\text { Mucoadhesive Mic- } \\
\text { roparticle }\end{array}$} & $\begin{array}{l}\text { Novel duodenum-specific drug delivery } \\
\text { system for duodenal application, based } \\
\text { on thiolated chitosan and hydroxypro- } \\
\text { pyl methylcellulose acetate maleate } \\
\text { (HPMCAM) }\end{array}$ & $\begin{array}{l}90 \% \text { of the drug released } \\
\text { within } 6 \mathrm{~h}\end{array}$ & Liu et al., 2011 \\
\hline & $\begin{array}{l}\text { Mucoadhesive microparticle formulation } \\
\text { prepared using the dual channel spray } \\
\text { gun technology }\end{array}$ & $\begin{array}{l}\text { Increased plasma concentra- } \\
\text { tion by } 6.98 \text { folds and de- } \\
\text { creased the tumor volume by } \\
49.8-53.4 \% \text { when compared to } \\
\text { untreated control groups }\end{array}$ & $\begin{array}{l}\text { Godugu, Patel, Dod- } \\
\text { dapaneni, Somago- } \\
\text { ni, \& Singh, } 2014\end{array}$ \\
\hline \multirow[t]{3}{*}{ Adjuvant } & $\begin{array}{l}\text { Nanosystem-based adjuvants with Ba- } \\
\text { icalin or berberine loaded ultradeform- } \\
\text { able vesicles }\end{array}$ & $\begin{array}{l}\text { In vitro study showed antioxi- } \\
\text { dant effect (baicalin vesicle) } \\
\text { and photoprotective effects } \\
\text { (berberine vesicle) }\end{array}$ & $\begin{array}{l}\text { Mir-Palomo et al., } \\
2019\end{array}$ \\
\hline & Coptidis rhizome and berberine & $\begin{array}{l}\text { In vitro study, showed correla- } \\
\text { tion of Coptidis rhizome and } \\
\text { berberine with the ECC line } \\
\text { which decreased the S phase } \\
\text { and accumulation of cells in } \\
\text { the G0/G1 phase in esopha- } \\
\text { geal cancer. }\end{array}$ & lizuka et al., 2000 \\
\hline & BBR and palmatine & $\begin{array}{l}\text { In vitro study showed that } \\
\text { a combination of BBR and } \\
\text { palmatine inhibits the ace- } \\
\text { tylcholinesterases using the } \\
\text { recombinant human acetyl- } \\
\text { cholinesterases. }\end{array}$ & Mak et al., 2014 \\
\hline
\end{tabular}

ecules. Polymerized, microencapsulated, and polymer-coated liposome systems have been employed to increase the potential of oral drug delivery. A recent study reported the preparation of BBR-loaded solid proliposomes using water as the solution enhanced dispersion by using supercritical $\mathrm{CO}_{2}$ (SEDS) with an $80 \mathrm{~nm}$ size and high entrapment efficacy of $90.3 \%$ of BBR. In vivo study results indicated that the oral bioavailability of BBR-proliposomes was significantly improved following oral administration of a $150 \mathrm{mg} / \mathrm{kg}$ dose to rats. It was observed that the BBR-proliposomes resulted in higher blood plasma concentration $(227.08 \mu \mathrm{g} / \mathrm{mL})$ than that of the plain BBR $(23.50$ $\mu \mathrm{g} / \mathrm{mL}$ ). The in vitro drug release study indicated sustained release of BBR-proliposomes (Jia et al., 2019). In vitro and in vivo study for the chitosan-coated nano-liposome for the oral delivery of berberine hydrochloride $(\mathrm{BH})$ carried out in rabbits demonstrated a marked improvement in the pharmacokinetic parameters after oral administration when compared to the uncoated nano-liposome. Also, the in vitro study showed improved stability and delayed $\mathrm{BH}$ release in the simulated gastrointestinal (Gl) environment (Nguyen et al., 2014). 32-full factorial design was employed for the preparation of liposome. It was observed that the formulated liposome system increased the lipid concentration with the highest entrapment efficiency (78.43\%). By increasing the plasma concentration levels and lowering the kinetics of elimination, micelles and phospholipid complexes are reported to enhance the gastrointestinal absorption of natural drugs thereby improving their bioavailability (Sailor, Seth, Parmar, Chauhan, \& Javia,
2015). A significant improvement in BBR bioavailability was reported due to berberine-loaded anhydrous reverse micelle (ARMs) formulation. In this study, BBR (100 mg/kg) was administered orally to diabetic rats, and berberine anhydrous reverse micelle (ARM) exhibited a maximum plasma concentration of $0.628 \mu \mathrm{g} / \mathrm{mL}$ at $4 \mathrm{~h}$ after oral administration as compared to that of berberine solution(a maximum plasma concentration of $0.298 \mu \mathrm{g} / \mathrm{mL}$ at $2 \mathrm{~h}$ after oral dosing). About a 2.4-fold increase in oral bioavailability of berberine from the BBR-loaded ARMs in rats was observed over the free BBR. The results of the study indicated that the BBR-loaded ARMs can significantly increase the plasma level of active BBR in rats (Wang et al., 2011). The in vitro and in vivo anticancer activity of polymeric phospholipid micelles containing BBR was studied. In the in vitro study, faster release of berberine-mixed 1,2-disteroyl-snglycero-3-phosphoethanolamine- $\mathrm{N}$-[methoxy(polyethylenegl ycol)-2000] (PEG-PE) mixed with D-a-tocopherylpolyethylene glycol 1000 succinate (TPGS) was observed (61\% berberine release after $24 \mathrm{~h}$ ). In the in vivo part of this study, the effect of berberine-mixed 1,2-distearoyl-sn-glycero-3-phosphoethanolamine-N-[methoxy (polyethyleneglycol)- 2000] (PEG-PE) and d-a-tocopheryl polyethylene glycol 1000 succinate (TPGS) micelle system (mMic) was evaluated in comparison to free berberine;enhancement of the intestinal absorption of approximately 3-to-5-fold (maximum plasma concentration of $1.22 \mathrm{mg} / \mathrm{kg}$ ) was observed after a $300 \mathrm{mg} / \mathrm{kg}$ oral dose (Shen, Kim, Yao, \& Elbayoumi, 2016). 


\section{Microemulsion}

As a potentially excellent vehicle candidate, microemulsions can increase the solubility of bioactive materials and can also improve the absorption through human gut membrane because of their extremely low surface tension. Drugs can directly contact the Gl epithelium cell; consequently, the bioavailability can be significantly improved (Swenson \& Curatolo, 1992; O'Driscoll, 2002). Gui et al. have prepared and evaluated the oral microemulsion formulation of BBR (24.0 nm size) which was found to be stable at room temperature. An in vivo study with male Sprague-Dawley rats (50 mg/kg oral dose) demonstrated improved bioavailability of the oral berberine-loaded microemulsion formulation, which was 6.47 times greater than that of the berberine tablet suspension at $7.3 \mathrm{~h}$ of the study (Gui et al., 2008). Berberine hydrochloric microemulsion for antibacterial activity was developed and characterized by Sun and Ouyang (2007). The formulated microemulsion (56.8 $\mathrm{nm}$ size) was found to be stable under high temperatures and strong light conditions and gave a prolonged in vitro release of berberine. The in vivo study in rats resulted in improved antibacterial activity employing the microemulsion when compared to the other dosage forms. Zhu et al. developed selfmicroemulsifying drug delivery system (SMEDDS) to improve the oral bioavailability of $\mathrm{BH}$. The in vitro study indicated faster release of BBR from SMEDDS (5h) as compared to the commercial tablet formulation, with improved stability. In the in vivo study in rats, the effect of SMEDDS was evaluated in comparison to commercial tablet formulation; the plasma concentration was found to be $163.4 \%$ higher than the commercial tablet following the administration of a $25 \mathrm{mg} / \mathrm{kg}$ oral dose (Zhu et al., 2013). A previous study demonstrated that the cremophore-integrated chylomicron, "cremochylomicrons," loaded with BBR inhibited the BBR absorption (43\%) and confirmed the lymphatic targeting ability of the cremochylomicrons. In the in vivo part of this study, the effect of the formulated cremochylomicron was evaluated in comparison to free BBR in rat model. The comparison of the effect of cremochylomicron with free BBR gave a significant enhancement ( $>2$ fold) in rate and extent of absorption of BBR (Elsheikh, Elnaggar, Hamdy, \& Abdallah, 2018). Another study showed that the berberineloaded chylomicron increased the intracellular fluorescence 2-fold, using confocal microscopy analysis with a 10.5-fold enhancement in intestinal permeability over free BBR. Therefore, berberine-loaded chylomicron is considered as an attractive bioactive-nanocarrier for berberine lymphatic targeting and bioavailability improvement (Godugu, Patel, Doddapaneni, Somagoni, \& Singh, 2014).

\section{Mucoadhesive microparticles}

Chen et al. developed and optimized a novel mucoadhesive drug delivery system (drug-resin complex core loaded with BHberberine hydrochloride) which influences the gastric retention of berberine ( $85 \%$ at 300 min of the study) (Chen et al., 2008). A novel duodenum-specific drug delivery system for duodenal application, based on thiolated chitosan and hydroxypropyl methylcellulose acetate maleate (HPMC-AM), which is used for the coating of thiolated chitosan microspheres,was also reported. The in vitro study showed that $90 \%$ of the BBR was released within $6 \mathrm{~h}$ after transferring into simulated patho- logical duodenal fluid (SPDF) (Liu et al., 2011). Mucoadhesive microparticle formulation prepared using the dual channel spray gun technology significantly increased the oral bioavailability and anticancer effects of BBR. The in vivo study in Sprague Dawley rats demonstrated increased plasma concentration of BBR by 6.98-fold and decreased the tumor volume by $49.8-53.4 \%$ when compared to the untreated control group (Godugu et al., 2014).

\section{Adjuvant}

SilviaA previous study formulated and characterized nanosystem-based adjuvants with baicalin/berberine-loaded ultradeformable vesicles for the treatment of vitiligo. The This in vitro study showed the antioxidant effect (baicalin vesicle) and photoprotective effects (berberine vesicle) through the stimulation of melanin production and tyrosinase activity in melanocytes (Mir-Palomo et al., 2019). Coptidis rhizome and BBR, a known inhibitor of the proliferation of human esophageal cancer cell (ECCs) lines, were administered in human volunteers. The in vitro study showed a good correlation of the treatment with Coptidis rhizome and BBR on the ECC line, which decreased the $S$ phase and the accumulation of cells in the G0/G1 phase, proving to be useful alternative therapies for oesophageal cancer (lizuka et al., 2000). BBR and palmatine, when used in combination, exhibited synergistic effect. The in vitro study showed that the combination of BBR and palmatine inhibits the acetylcholinesterases, using the recombinant human acetylcholinesterases. The drug-reducing index of BBR and palmatine were found to be 2.98 and 2.66, respectively, which might be beneficial in the treatment of patients with Alzheimer disease (Mak et al., 2014). The antimicrobial activity of BBR against Methicillin-resistant Staphylococcus aureus (MRSA) (90\%), the synergistic effect between BBR and oxacillin against MRSA, and the additive effect between BBR and ampicillin were observed. BBR (1-50 $\mu \mathrm{g} / \mathrm{mL})$, compared with the vehicle-treated control group, decreased MRSA adhesion and intracellular invasion in human gingival fibroblasts (Yu et al., 2005). Thus, overall, these studies indicated that the activity of BBR can be modulated both at the cellular level and at the organismic level, and we can expect surprising types of regulations when different agents are used simultaneously with BBR.

\section{Derivatives and analogues}

The chemical structure of BBR plays a crucial role in its biological activity. For example, isomerization has proved to have a significant influence on the antioxidant activity of BBR. Thus, several researchers are working on the effective structural modification of BBR with the aim to achieve a better biological response. Numerous studies dealing with the improved biological activity of BBR derivatives and/or analogues can be found in the literature. Shan et al., in their study, designed the BBR analogue, designated IMB-Y53, which was reported to display improved glucose-lowering efficacy both in the in vitro and in vivo studies in comparison to BBR. In this study, the maximum tolerable dose of IMB-Y53 following oral administration to male wistar rats was 200 mg/kg. IMB-Y53 absorption was rapid after oral administration. The maximum plasma concentration of nearly $5.84 \mathrm{ng} / \mathrm{ml}$ was detected $2 \mathrm{~h}$ after the oral 
dose. In the in vitro study, when IMB-Y53 (40 $\mu \mathrm{M})$ was orally administered, in the C2C12 cells, IMB-Y53 up-regulated InsR mRNA by 2.3-fold and protein expression levels by 1.9-fold. IMB-Y53 (20 $\mu \mathrm{M}-40 \mu \mathrm{M})$ stimulated the glucose consumption by 1.5-1.7 fold in the muscle cells. Another strategy to improve the biological activity of BBR involved the synthesis of new 13-diphenylalkyl analogues of BBR. The presence of the diphenylalkyl chain at the 13-position of BBR significantly improved the binding ability to the DNA (Shan et al., 2013). BBR is a novel cholesterol-lowering agent acting through a mechanism different from that of statins; the two methoxyl groups in an ortho-distribution (10- and 11-position) on the benzene ring increased the low-density-lipoprotein receptor (LDLR) upregulatory activity (Kawanishi et al., 2006). Another group of researchers also designed, synthesized, and evaluated new BBR analogues that can up-regulate the low-density-lipoprotein receptor (LDLR). Accordingly, BBR analogues with the methylene dioxy group at the 2-and 3-position were reported to be the essential requirements for the activity. The in vivo study in hyperlipidemicrats $(100 \mathrm{mg} / \mathrm{kg} /$ day) decreased the blood cholesterol by $42.6 \%$ and LDL-c by $49.4 \%$ (Li et al., 2009). Although many BBR analogues are found to show improved biological activity over BBR, specific evaluation of structural analogues and/or derivatives of BBR demonstrated no significant improvement in the tissue and plasma distribution. However, the promising biological effects of the modified BBR derivatives/ analogues compared to BBR throws light onto the possibility of modulating the bioavailability of BBR through such structural modifications.

\section{CONCLUSIONS}

Berberine is a quaternary ammonium salt from the protoberberine group of benzylisoquinoline alkaloids which has been used for centuries as a remedy for many ailments. Extensive scientific research over the past decade has shown the ability of this compound to modulate multiple cellular targets and hence display favorable preventive and therapeutic action for the treatment of a wide variety of diseases. BBR acts on a diverse range of molecular targets like transcription factors, growth factors and their receptors, cytokines, enzymes, and genes regulating cell proliferation and apoptosis, and inflammatory factors. As detailed in this review, tissue levels of BBR, irrespective of the route of administration, exhibited rapid metabolism and elimination, which are the major factors limiting its bioavailability. Effective modulation of the route and the medium of BBR administration, the blocking of metabolic pathways by the concomitant administration with other agents, and structural modifications are the main strategies that are now being explored to improve the bioavailability of BBR. Attempts to enhance the in vitro and in vivo efficacy of BBR through structural modifications of the molecule and/or new formulations have been recently reported and explored. This review outlines the challenges in the bioavailability improvement of BBR and the various solutions being researched to tackle this issue. Varied novel delivery strategies, including those of nanosized dosage forms, liposomes, and phospholipid complexes, offer significant promise and are worthy of further exploration in attempts to enhance the bioavailability, medicinal value, and application of this interesting molecule from Mother Nature.

Acknowledgements: The authors would like to thank Dr. D. Y. Patil Institute of Pharmaceutical Sciences and Research, Pune, Maharashtra. India for providing the necessary infrastructural facilities to carry out this work.

Peer-review: Externally peer-reviewed.

Author Contributions: Conception/Design of Study- A.T., S.D.; Data Acquisition- A.T., S.K., S.D., L.K., S.C.; Data Analysis/Interpretation- A.T., S.K., S.D., L.K., S.C.; Drafting Manuscript- A.T., S.K.; Critical Revision of Manuscript- A.T., S.K., S.D., L.K., S.C.; Final Approval and AccountabilityA.T., S.K., S.D., L.K., S.C.

Conflict of Interest: The authors have no conflict of interest to declare.

Financial Disclosure: Authors declared no financial support.

\section{REFERENCES}

- $\quad$ Affuso, F., Ruvolo, A., Micillo, F., Saccà, L., \& Fazio, S. (2010). Effects of a nutraceutical combination (berberine, red yeast rice and policosanols) on lipid levels and endothelial function randomized, double-blind, placebo-controlled study. Nutrition, Metabolism and Cardiovascular Diseases, 20(9), 656-661.

- $\quad$ Affuso, F., Mercurio, V., Ruvolo, A., Pirozzi, C., Micillo, F., Carlomagno, G., ... \& Fazio, S. (2012). A nutraceutical combination improves insulin sensitivity in patients with metabolic syndrome. World journal of cardiology, 4(3), 77.

- $\quad$ Agarwal, M., Srivastava, V. K., Saxena, K. K., \& Kumar, A. (2006). Hepatoprotective activity of Beta vulgaris against CCl4-induced hepatic injury in rats. Fitoterapia, 77(2), 91-93.

- $\quad$ Ali, H., Uddin, S., \& Jalal, S. (2015). Chemistry and biological activities of Berberis lyciumRoyle. Journal of Biologically Active Products from Nature, 5(5), 295-312.

- $\quad$ Andreicut,, A. D., Parvu, A. E., Moț, A. C., Parvu, M., Fischer-Fodor, E. V. A., Feldrihan, V., ... \& Irimie, A. (2018). Anti-inflammatory and antioxidant effects of Mahonia aquifolium leaves and bark extracts. Farmacia, 66(1).

- Bajpai, D., \& Vankar, P. S. (2007). Antifungal textile dyeing withmahonianapaulensis dc leaves extract based on its antifungal activity. Fibers and Polymers, 8(5), 487.

- Battu, S. K., Repka, M. A., Maddineni, S., Chittiboyina, A. G., Avery, M. A., \& Majumdar, S. (2010). Physicochemical characterization of berberine chloride: a perspective in the development of a solution dosage form for oral delivery. Aaps Pharmscitech, 11(3), 1466-1475.

- $\quad$ Bhandari, D. K., Nath, G., Ray, A. B., \& Tewari, P. V. (2000). Antimicrobial activity of crude extracts from Berberis asiatica stem bark. Pharmaceutical Biology, 38(4), 254-257.

- $\quad$ Biswas, T. K., \& Mukherjee, B. (2003). Plant medicines of Indian origin for wound healing activity: a review. The International Journal of Lower Extremity Wounds, 2(1), 25-39.

- Čerňáková, M., \& Koštálová, D. (2002). Antimicrobial activity of berberine-A constituent of Mahonia aquifolium. Folia Microbiologica, 47(4), 375-378.

- Chang, C. H., Huang, W. Y., Lai, C. H., Hsu, Y. M., Yao, Y. H., Chen, T. Y., ... \& Lin, Y. H. (2011). Development of novel nanoparticles shelled with heparin for berberine delivery to treat Helicobacter pylori. Acta Biomaterialia, 7(2), 593-603.

- Chatterjee, P., \& Franklin, M. R. (2003). Human cytochrome p450 inhibition and metabolic-intermediate complex formation by goldenseal extract and its methylenedioxyphenyl components. Drug Metabolism and Disposition, 31(11), 1391-1397. 
- Chen, F., Zhang, Y., Liu, Q., Pang, M. Z., Yang, X. G., \& Pan, W. S. (2008). Optimization of a novel mucoadhesive drug deliver system with ion-exchange resin core loaded with berberine hydrochloride using central composite design methodology. Yao xuexue bao= Acta Pharmaceutica Sinica, 43(9), 963-968.

- $\quad$ Chen, W., Miao, Y. Q., Fan, D. J., Yang, S. S., Lin, X., Meng, L. K., \& Tang, X. (2011). Bioavailability study of berberine and the enhancing effects of TPGS on intestinal absorption in rats. Aaps Pharmscitech, 12(2), 705-711.

- $\quad$ Cicero, A. F., Rovati, L. C., \& Setnikar, I. (2007). Eulipidemic effects of berberine administered alone or in combination with other natural cholesterol-lowering agents. Arzneimittelforschung, 57(01), 2630.

- Das, N. G., Rabha, B., Talukdar, P. K., Goswami, D., \& Dhiman, S. (2016). Preliminary in vitro antiplasmodial activity of Aristolochiagriffithii and Thalictrum foliolosum DC extracts against malaria parasite Plasmodium falciparum. BMC Research Notes, 9(1), 51.

- Das, S., Das, M. K., Mazumder, P. M., Das, S., \& Basu, S. P. (2009). Cytotoxic activity of methanolic extract of Berberis aristata DC on colon cancer. Global Journal of Pharmacology, 3(3), 137-140.

- Deng, Y., Liao, Q., Li, S., Bi, K., Pan, B., \& Xie, Z. (2008). Simultaneous determination of berberine, palmatine and jatrorrhizine by liquid chromatography-tandem mass spectrometry in rat plasma and its application in a pharmacokinetic study after oral administration of coptis-evodia herb couple. Journal of Chromatography B, 863(2), 195-205.

- Elsheikh, M. A., Elnaggar, Y. S., Hamdy, D. A., \& Abdallah, O. Y. (2018). Novel cremochylomicrons for improved oral bioavailability of the antineoplastic phytomedicine berberine chloride: Optimization and pharmacokinetics. International Journal of Pharmaceutics, 535(1-2), 316-324.

- $\quad$ Eto, T., Inoue, S., \& Kadowaki, T. (2012). Effects of once-daily teneligliptin on 24-h blood glucose control and safety in Japanese patients with type 2 diabetes mellitus: a 4-week, randomized, double-blind, placebo-controlled trial. Diabetes, Obesity and Metabolism, 14(11), 1040-1046.

- $\quad$ Ettefagh, K. A., Burns, J. T., Junio, H. A., Kaatz, G. W., \& Cech, N. B. (2011). Goldenseal (Hydrastis canadensis L.) extracts synergistically enhance the antibacterial activity of berberine via efflux pump inhibition. Planta Medica, 77(08), 835-840.

- Godugu, C., Patel, A. R., Doddapaneni, R., Somagoni, J., \& Singh, M. (2014). Approaches to improve the oral bioavailability and effects of novel anticancer drugs berberine and betulinic acid. PloS one, 9(3), e89919.

- $\quad$ Gong, Z., Chen, Y., Zhang, R., Wang, Y., Guo, Y., Yang, Q., ... \& Zhu, X. (2014a). Pharmacokinetic comparison of berberine in rat plasma after oral administration of berberine hydrochloride in normal and post inflammation irritable bowel syndrome rats. International journal of molecular sciences, 15(1), 456-467.

- $\quad$ Gong, Z., Chen, Y., Zhang, R., Wang, Y., Yang, Q., Guo, Y., ... \& Wang, Y. (2014). Pharmacokinetics of two alkaloids after oral administration of Rhizoma Coptidis extract in normal rats and irritable bowel syndrome rats. Evidence-Based Complementary and Alternative Medicine, 2014.

- Gulfraz, M., Mehmood, S., Ahmad, A., Fatima, N., Praveen, Z., \& Williamson, E. M. (2008). Comparison of the antidiabetic activity of Berberis lyceum root extract and berberine in alloxan-induced diabetic rats. Phytotherapy Research, 22(9), 1208-1212.

- $\quad$ Gui, S. Y., Wu, L., Peng, D. Y., Liu, Q. Y., Yin, B. P., \& Shen, J. Z. (2008). Preparation and evaluation of a microemulsion for oral delivery of berberine. Die Pharmazie-An International Journal of Pharmaceutical Sciences, 63(7), 516-519.
Gurley, B. J., Swain, A., Hubbard, M. A., Hartsfield, F., Thaden, J., Williams, D. K., ... \& Tong, Y. (2008). Supplementation with goldenseal (Hydrastis canadensis), but not kava kava (Piper methysticum), inhibits human CYP3A activity in vivo. Clinical Pharmacology \& Therapeutics, 83(1), 61-69.

Hu, Y. L., Chen, C., Zou, Z. Y., Li, X. G., \& Ye, X. L. (2014). Comparative study of pharmacokinetics and tissue distribution of 8-cetylberberine and berberine in rats. Acta Pharmaceutica Sinica, 49(11), 1582.

Hussain, M. A., Khan, M. Q., Habib, T., \& Hussain, N. (2011). Antimicronbial activity of the crude root extract of Berberis lycium Royle. Advances in Environmental Biology, 5(4), 585-588.

- lizuka, N., Miyamoto, K., Okita, K., Tangoku, A., Hayashi, H., Yosino, S., ... \& Oka, M. (2000). Inhibitory effect of Coptidis Rhizoma and berberine on the proliferation of human esophageal cancer cell lines. Cancer Letters, 148(1), 19-25.

- Inbaraj, J. J., Kukielczak, B. M., Bilski, P., Sandvik, S. L., \& Chignell, C. F. (2001). Photochemistry and photocytotoxicity of alkaloids from Goldenseal (Hydrastis canadensis L.) 1. Berberine. Chemical Research in Toxicology, 14(11), 1529-1534.

- Jia, J., Zhang, K., Zhou, X., Ma, J., Liu, X., Xiang, A., \& Ge, F. (2019). Berberine-loaded solid proliposomes prepared using solution enhanced dispersion by supercritical CO2: Sustained release and bioavailability enhancement. Journal of Drug Delivery Science and Technology, 51, 356-363.

- Jia, Y., Xu, B., \& Xu, J. (2017). Effects of type 2 diabetes mellitus on the pharmacokinetics of berberine in rats. Pharmaceutical Biology, 55(1), 510-515.

Jigneshkumar, P. R. (2011). Evaluation of the Antihyperglycemic, Cardio protective and Antihyperlipidemic activity of flowers of Sesbania grandiflora (Linn) (Doctoral dissertation, RGUHS).

- Joshi, P. V., Shirkhedkar, A. A., Prakash, K., \& Maheshwari, V. L. (2011). Antidiarrheal activity, chemical and toxicity profile of Berberis aristata. Pharmaceutical Biology, 49(1), 94-100.

- Kawanishi, N., Sugimoto, T., Shibata, J., Nakamura, K., Masutani, K., Ikuta, M., \& Hirai, H. (2006). Structure-based drug design of a highly potent CDK1, 2, 4, 6 inhibitor with novel macrocyclic quinoxalin-2-one structure. Bioorganic \& Medicinal Chemistry Letters, 16(19), 5122-5126.

Kobayashi, Y., Yamashita, Y., Fujii, N., Takaboshi, K., Kawakami, T., Kawamura, M., ... \& Nakano, H. (1995). Inhibitors of DNA topoisomerase I and II isolated from the Coptis rhizomes. Planta Medica, 61(05), 414-418.

- $\quad$ Kong, W. J., Wei, J., Zuo, Z. Y., Wang, Y. M., Song, D. Q., You, X. F., ... \& Jiang, J. D. (2008). Combination of simvastatin with berberine improves the lipid-lowering efficacy. Metabolism, 57(8), 1029-1037. Kong, W. J., Wei, J., Zuo, Z. Y., Wang, Y. M., Song, D. Q., You, X. F., ... \& Jiang, J. D. (2008). Combination of simvastatin with berberine improves the lipid-lowering efficacy. Metabolism, 57(8), 1029-1037. Kong, W. J., Zhao, Y. L., Xiao, X. H., Wang, J. B., Li, H. B., Li, Z. L., ... \& Liu, Y. (2009). Spectrum-effect relationships between ultra performance liquid chromatography fingerprints and anti-bacterial activities of Rhizoma coptidis. Analytica Chimica Acta, 634(2), 279285.

- $\quad$ Lee, H. W., Suh, J. H., Kim, H. N., Kim, A. Y., Park, S. Y., Shin, C. S., .. \& Kim, J. B. (2008). Berberine promotes osteoblast differentiation by Runx2 activation with p38 MAPK. Journal of Bone and Mineral Research, 23(8), 1227-1237.

Lee, M. K., Zhang, Y. H., \& Kim, H. S. (1996). Inhibition of tyrosine hydroxylase by palmatine. Archives of Pharmacal Research, 19(4), 258. Li, Y. H., Yang, P., Kong, W. J., Wang, Y. X., Hu, C. Q., Zuo, Z. Y., ... \& Du, N. N. (2009). Berberine Analogues as a novel class of the lowdensity-lipoprotein receptor up-regulators: synthesis, structureactivity relationships, and cholesterol-lowering efficacy. Journal of Medicinal Chemistry, 52(2), 492-501. 
- $\quad$ Li, Y., Wang, H., Si, N., Ren, W., Han, L., Xin, S., ... \& Bian, B. (2015) Metabolic profiling analysis of berberine, palmatine, jatrorrhizine, coptisine and epiberberine in zebrafish by ultra-high performance liquid chromatography coupled with LTQ Orbitrap mass spectrometer. Xenobiotica, 45(4), 302-311.

- $\quad$ Liu, Y., Hao, H., Xie, H., Lv, H., Liu, C., \& Wang, G. (2009). Oxidative demethylenation and subsequent glucuronidation are the major metabolic pathways of berberine in rats. Journal of Pharmaceutical Sciences, 98(11), 4391-4401.

- Liu, Y. H., Zhu, X., Zhou, D., Jin, Y., Zhao, C. Y., Zhang, Z. R., \& Huang, Y. (2011). pH-sensitive and mucoadhesive microspheres for duodenum-specific drug delivery system. Drug Development and Industrial Pharmacy, 37(7), 868-874.

- Liu, Y. T., Hao, H. P., Xie, H. G., Lai, L., Wang, Q., Liu, C. X., \& Wang, G. J. (2010). Extensive intestinal first-pass elimination and predominant hepatic distribution of berberine explain its low plasma levels in rats. Drug Metabolism and Disposition, 38(10), 1779-1784.

- $\quad$ Liu, J., Tu, L., Cheng, M., Feng, J., \& Jin, Y. (2020). Mechanisms for oral absorptionenhancement of drugs by nnocrystals. Journal of Drug Delivery Science and Technology, 101607.

- Ma, J.Y., Feng, R., Tan, X. S., Ma, C., Shou, J. W., Fu, J., ... \& He, W. Y. (2013). Excretion of berberine and its metabolites in oral administration in rats. Journal of Pharmaceutical Sciences, 102(11), 4181-4192.

- Mak, S., Luk, W. W., Cui, W., Hu, S., Tsim, K. W., \& Han, Y. (2014). Synergistic inhibition on acetylcholinesterase by the combination of berberine and palmatine originally isolated from Chinese medicinal herbs. Journal of Molecular Neuroscience, 53(3), 511-516.

- Malairajan, P., Gopalakrishnan, G., Narasimhan, S., \& Veni, K. J. K. (2008). Evalution of anti-ulcer activity of Polyalthia longifolia (Sonn.) Thwaites in experimental animals. Indian Journal of Pharmacology, 40(3), 126.

- Mir-Palomo, S., Nácher, A., Busó, M. O. V., Caddeo, C., Manca, M. L., Manconi, M., \& Díez-Sales, O. (2019). Baicalin and berberine ultradeformable vesicles as potential adjuvant in vitiligo therapy. Colloids and Surfaces B: Biointerfaces, 175, 654-662.

- Nair, G. M., Narasimhan, S., Shiburaj, S., \& Abraham, T. K. (2005). Antibacterial effects of Coscinium fenestratum. Fitoterapia, 76(6), 585-587.

- Neag, M. A., Mocan, A., Echeverría, J., Pop, R. M., Bocsan, C. I., Crişan, G., \& Buzoianu, A. D. (2018). Berberine: Botanical occurrence, traditional uses, extraction methods, and relevance in cardiovascular, metabolic, hepatic, and renal disorders. Frontiers in Pharmacology, 9, 557.

- $\quad$ Nguyen, T. X., Huang, L., Liu, L., Abdalla, A. M. E., Gauthier, M., \& Yang, G. (2014). Chitosan-coated nano-liposomes for the oral delivery of berberine hydrochloride. Journal of Materials Chemistry B, 2(41), 7149-7159.

- O'Driscoll, C. M. (2002). Lipid-based formulations for intestinal lymphatic delivery. European Journal of Pharmaceutical Sciences, 15(5), 405-415.

- Owokotomo, I. A., \& Owoeye, G. (2011). Proximate analysis and antimicrobial activities of Bambusa vulgaris $L$. leaves' beverage. African Journal of Agricultural Research, 6(21), 5030-5032.

- $\quad$ Patil, S., Dash, R. P., Anandjiwala, S., \& Nivsarkar, M. (2012). Simultaneous quantification of berberine and lysergol by HPLC-UV: evidence that lysergol enhances the oral bioavailability of berberine in rats. Biomedical Chromatography, 26(10), 1170-1175.

- $\quad$ Pirbalouti, A. G., Azizi, S., Koohpayeh, A., \& Hamedi, B. (2010). Wound healing activity of Malva sylvestris and Punica granatum in alloxan-induced diabetic rats. Acta Poloniae Pharmaceutica, 67(5), 511-516.

- Qiu, F., Zhu, Z., Kang, N., Piao, S., Qin, G., \& Yao, X. (2008). Isolation and identification of urinary metabolites of berberine in rats and humans. Drug Metabolism and Disposition, 36(11), 2159-2165.
Rockova, L., Majekova, M., Kost, D., \& Stefek, M. (2004). Antiradical and antioxidant activities of alkaloids isolated from Mahonia aquifolium. Structural Aspects Bioorganic \& Medicinal Chemistry, 12, 4709-4715.

Sahibzada, M. U. K., Sadiq, A., Faidah, H. S., Khurram, M., Amin, M. U., \& Haseeb, A. (2018). Berberine nanoparticles with enhanced in vitro bioavailability: characterization and antimicrobial activity. Drug Design, Development and Therapy, 12: 303-12.

- $\quad$ Sailor, G., Seth, A. K., Parmar, G., Chauhan, S., \& Javia, A. (2015). Formulation and in vitro evaluation of berberine containing liposome optimized by 32 full factorial designs. Journal of Applied Pharmaceutical Science, 5(7), 023-028.

- $\quad$ Sarna, L. K., Wu, N., Hwang, S. Y., Siow, Y. L., \& O, K. (2010). Berberine inhibits NADPH oxidase mediated superoxide anion production in macrophages. Canadian Journal of Physiology and Pharmacology, 88(3), 369-378.

- Semwal, B. C., Gupta, J., Singh, S., Kumar, Y., \& Giri, M. (2009). Antihyperglycemic activity of root of Berberis aristata DC in alloxaninduced diabetic rats. International Journal of Green Pharmacy (IJGP), 3(3).

Shan, Y. Q., Ren, G., Wang, Y. X., Pang, J., Zhao, Z. Y., Yao, J., ... \& Jiang, J. D. (2013). Berberine analogue IMB-Y53 improves glucose-lowering efficacy by averting cellular efflux especially P-glycoprotein efflux. Metabolism, 62(3), 446-456.

- Shen, R., Kim, J. J., Yao, M., \& Elbayoumi, T. A. (2016). Development and evaluation of vitamin E D-a-tocopheryl polyethylene glycol 1000 succinate-mixed polymeric phospholipid micelles of berberine as an anticancer nanopharmaceutical. International Journal of Nanomedicine, 11, 1687.

Shirwaikar, A., Rajendran, K., \& Punitha, I. S. R. (2005a). Antidiabetic activity of alcoholic stem extract of Coscinium fenestratum in streptozotocin-nicotinamide induced type 2 diabetic rats. Journal of Ethnopharmacology, 97(2), 369-374.

- Shirwaikar, A., Rajendran, K., \& Punitha, I. S. R. (2005b). Antihyperglycemic Activity of the Aqueous Stem Extract of Coscinium fenestratum. in Non-insulin Dependent Diabetic Rats. Pharmaceutical Biology, 43(8), 707-712.

Singh, M., Srivastava, S., \& Rawat, A. K. S. (2007). Antimicrobial activities of Indian Berberis species. Fitoterapia, 78(7-8), 574-576. Singh, P., \& Jain, S. (2010). Antidiabetic activity of Berberis asiatica (DC) roots. International Journal of Pharmaceutical Sciences and Research, 1, 109-112.

Singh, S. K., Vishnoi, R., Dhingra, G. K., \& Kishor, K. (2012). Antibacterial activity of leaf extracts of some selected traditional medicinal plants of Uttarakhand, North East India. Journal of Applied and Natural Science, 4(1), 47-50.

Soudi, S. A., Nounou, M. I., Sheweita, S. A., Ghareeb, D. A., Younis, L. K., \& El-Khordagui, L. K. (2019). Protective effect of surface-modified berberine nanoparticles against LPS-induced neurodegenerative changes: a preclinical study. Drug Delivery and Translational Research, 9(5), 906-919.

- $\quad$ Sun, S., Wang, K., Lei, H., Li, L., Tu, M., Zeng, S., ... \& Jiang, H. (2014). Inhibition of organic cation transporter 2 and 3 may be involved in the mechanism of the antidepressant-like action of berberine. Progress in Neuro-Psychopharmacology and Biological Psychiatry, 49, 1-6.

Swenson, E. S., \& Curatolo, W. J. (1992). Intestinal permeability enhancement for proteins, peptides and other polar drugs: mechanisms and potential toxicity. Advanced Drug Delivery Reviews, 8(1), 39-92.

Tan, X. S., Ma, J. Y., Feng, R., Ma, C., Chen, W. J., Sun, Y. P., ... \& He, W. Y. (2013). Tissue distribution of berberine and its metabolites after oral administration in rats. PloS one, 8(10), e77969. 
- $\quad$ Tomosaka, H., Chin, Y. W., Salim, A. A., Keller, W. J., Chai, H., \& Kinghorn, A. D. (2008). Antioxidant and cytoprotective compounds from Berberis vulgaris (barberry). Phytotherapy Research, 22(7), 979-981.

- $\quad$ Tsai, P. L., \& Tsai, T. H. (2004). Hepatobiliary excretion of berberine. Drug Metabolism and Disposition, 32(4), 405-412.

- Villinski, J., Dumas, E., Chai, H. B., Pezzuto, J., Angerhofer, C., \& Gafner, S. (2003). Antibacterial activity and alkaloid content of Berberis thunbergii, Berberis vulgaris and Hydrastis canadensis. Pharmaceutical Biology, 41(8), 551-557.

- Wang, K., Feng, X., Chai, L., Cao, S., \& Qiu, F. (2017). The metabolism of berberine and its contribution to the pharmacological effects. Drug Metabolism Reviews, 49(2), 139-157.

- Wang, T., Wang, N., Song, H., Xi, X., Wang, J., Hao, A., \& Li, T. (2011). Preparation of an anhydrous reverse micelle delivery system to enhance oral bioavailability and anti-diabetic efficacy of berberine. European Journal of Pharmaceutical Sciences, 44(1-2), 127-135.

- Wang, X., Wang, R., Xing, D., Su, H., Ma, C., Ding, Y., \& Du, L. (2005). Kinetic difference of berberine between hippocampus and plasma in rat after intravenous administration of Coptidis rhizoma extract. Life Sciences, 77(24), 3058-3067.

- Wang, X., Xing, D., Wang, W., Su, H., Tao, J., \& Du, L. (2005). Pharmacokinetics of berberine in rat thalamus after intravenous administration of Coptidis rhizoma extract. The American Journal of Chinese Medicine, 33(06), 935-943.

- Wei, W., Zhao, H., Wang, A., Sui, M., Liang, K., Deng, H., ... \& Guan, Y. (2012). A clinical study on the short-term effect of berberine in comparison to metformin on the metabolic characteristics of women with polycystic ovary syndrome. European Journal of Endocrinology, 166(1), 99.

- Sun, H. W., \& OUYANG, W. Q. (2007). The preparation and antibacterial activity in vitro of berberine hydrochloric nanometer microemulsion. Journal of Northwest A \& F University (Natural Science Edition), 1.

- Xiao, L., Xue, Y., Zhang, C., Wang, L., Lin, Y., \& Pan, G. (2018). The involvement of multidrug and toxin extrusion protein 1 in the distribution and excretion of berberine. Xenobiotica, 48(3), 314-323.

- $\quad$ Xiong, W., Sang, W., Linghu, K.G., Zhong, Z,F., San Cheang, W., Li, J.,...\& Wang,Y.T.(2018). Dual-functional Brij-S20-modified nanocrystal formulation enhances the intestinal transport and oral bioavailability of berberine. International Journal of nanomedicine, 13,3781.

- Xue, M., Yang, M. X., Zhang, W., Li, X. M., Gao, D. H., Ou, Z. M., ... \& Yang, S. Y. (2013). Characterization, pharmacokinetics, and hypoglycemic effect of berberine loaded solid lipid nanoparticles. International Journal of Nanomedicine, 8, 4677.
Yi, L., Jian-Ping, G., Xu, X., \& Lixin, D. (2006). Simultaneous determination of baicalin, rhein and berberine in rat plasma by columnswitching high-performance liquid chromatography. Journal of Chromatography $B, 838(1), 50-55$

Yin, J., Hou, Y., Yin, Y., \& Song, X. (2017). Selenium-coated nanostructured lipid carriers used for oral delivery of berberine to accomplish a synergic hypoglycemic effect. International Journal of Nanomedicine, 12,8671.

- $\quad$ Yogesh, H. S., Chandrashekhar, V. M., Katti, H. R., Ganapaty, S., Raghavendra, H. L., Gowda, G. K., \& Goplakhrishna, B. (2011). Anti-osteoporotic activity of aqueous-methanol extract of Berberis aristata in ovariectomized rats. Journal of Ethnopharmacology, 134(2), 334-338.

- Yu, F., Ao, M., Zheng, X., Li, N., Xia, J., Li, Y., ... \& Chen, X. D. (2017). PEG-lipid-PLGA hybrid nanoparticles loaded with berberinephospholipid complex to facilitate the oral delivery efficiency. Drug Delivery, 24(1), 825-833.

- $\quad Y u$, H. H., Kim, K. J., Cha, J. D., Kim, H. K., Lee, Y. E., Choi, N. Y., \& You, Y. O. (2005). Antimicrobial activity of berberine alone and in combination with ampicillin or oxacillin against methicillin-resistant Staphylococcus aureus. Journal of Medicinal Food, 8(4), 454-461.

- Zhang, C. R., Schutzki, R. E., \& Nair, M. G. (2013). Antioxidant and anti-inflammatory compounds in the popular landscape plant Berberis thunbergii var. atropurpurea. Natural Product Communications, 8(2), 1934578X1300800207.

- Zhang, H., Wei, J., Xue, R., Wu, J. D., Zhao, W., Wang, Z. Z., ... \& Pan, H. N. (2010). Berberine lowers blood glucose in type 2 diabetes mellitus patients through increasing insulin receptor expression. Metabolism, 59(2), 285-292.

- $\quad$ Zhang, Y., Wang, X., Sha, S., Liang, S., Zhao, L., Liu, L., ... \& Wu, K. (2012a). Berberine increases the expression of NHE3 and AQP4 in sennosideA-induced diarrhoea model. Fitoterapia, 83(6), 10141022.

- $\quad$ Zhang, Q., Qian, Z., Pan, L., Li, H., \& Zhu, H. (2012b). Hypoxia-inducible factor 1 mediates the anti-apoptosis of berberine in neurons during hypoxia/ischemia. Acta Physiologica Hungarica, 99(3), 311 323.

- $\quad$ Zhao, Y., Collier, J. J., Huang, E. C., \& Whelan, J. (2014). Turmeric and Chinese goldthread synergistically inhibit prostate cancer cell proliferation and NF-kB signaling. Functional Foods in Health and Disease, 4(7), 312-339.

- $\quad$ Zhu, J. X., Tang, D., Feng, L., Zheng, Z. G., Wang, R. S., Wu, A. G., ... \& Zhu, Q. (2013). Development of self-microemulsifying drug delivery system for oral bioavailability enhancement of berberine hydrochloride. Drug Development and Industrial Pharmacy, 39(3), 499-506. 